\title{
Phytoplankton community response to a manipulation of bioavailable iron in HNLC waters of the subtropical Pacific Ocean
}

\author{
Melanie L. Eldridge ${ }^{1}$, Charles G. Trick ${ }^{3}$, Melissa B. Alm ${ }^{4}$, Giacomo R. DiTullio ${ }^{4}$, \\ Eden L. Rue ${ }^{5}$, Kenneth W. Bruland ${ }^{5}$, David A. Hutchins ${ }^{6}$, Steven W. Wilhelm ${ }^{1,2, *}$ \\ ${ }^{1}$ Department of Microbiology, and ${ }^{2}$ Center for Environmental Biotechnology, The University of Tennessee, \\ Knoxville, Tennessee 37996, USA \\ ${ }^{3}$ Department of Biology, The University of Western Ontario, London, Ontario N6A 5B7, Canada \\ ${ }^{4}$ Grice Marine Laboratory, College of Charleston, Charleston, South Carolina 29412, USA \\ ${ }^{5}$ Department of Ocean Sciences, The University of California Santa Cruz, Santa Cruz, California 95064, USA \\ ${ }^{6}$ College of Marine Sciences, The University of Delaware, Lewes, Delaware 19958, USA
}

\begin{abstract}
Studies in high nutrient, low chlorophyll (HNLC) regions have demonstrated that increased Fe availability results in an increase in phytoplankton biomass and changes in community composition. Here we present experiments in which the availability of iron (Fe) was increased or reduced to monitor the response of individual groups of phytoplankton (large eukaryotes, picoeukaryotes and cyanobacteria) by flow cytometry. Additions (0.5 to $5.0 \mathrm{nM} \mathrm{Fe}$ ) and reductions in available $\mathrm{Fe}$ (through addition of 1 to $10 \mathrm{nM}$ of the fungal siderophore desferrioxamine B) were made to enclosed communities from the South American eastern boundary current off Peru, where ambient dissolved Fe concentrations were $<100 \mathrm{pM}$. As predicted, chlorophyll concentrations increased in the added Fe treatments relative to the control, indicative of Fe limitation. Flow cytometry demonstrated that this was due to increases in the abundance of large eukaryotes that are Fe-starved under ambient conditions. Cyanobacterial abundance increased and decreased linearly with Fe availability, suggesting that cyanobacteria were Fe-limited but not Fe-starved. In contrast, picoeukaryote cell abundance increased with decreasing Fe availability, although chlorophyll cell ${ }^{-1}$ in this group responded in an inverse manner. The results demonstrate that members of the marine phytoplankton community respond differently to Fe availability, which may influence the outcome of biological competition among organisms in Fe-limited environments.
\end{abstract}

KEY WORDS: Fe limitation $\cdot$ Fe Uptake $\cdot$ Desferrioxamine B $\cdot$ Picoeukaryotes Resale or republication not permitted without written consent of the publisher

\section{INTRODUCTION}

Ecosystem-scale Fe-fertilization experiments have provided conclusive evidence that the availability of Fe to phytoplankton in open-ocean high nutrient, low chlorophyll (HNLC) environments can limit primary production (Martin et al. 1994, Coale et al. 1996, Boyd et al. 2000). Moreover, on-deck bottle incubation experiments have demonstrated that Fe-limited HNLC conditions can also occur in coastal environments, when low riverine and aeolian Fe inputs are combined with high levels of upwelled nutrients (Hutchins \& Bruland 1998, Hutchins et al. 1998, Bruland et al. 2001, Firme et al. 2003). Recently, Hutchins et al. (2002) have demonstrated similar Fe-limiting conditions at 2 stations in the subtropical equatorial eastern Pacific Ocean off the coast of Peru. Although the upwelling regions along the western coasts of the temperate continents cover only a small percentage of the ocean's surface, they make a significant contribution to global biogeochemical cycles (Chavez 1995, Lluch-Cota 2000). It has been estimated that coastal upwelling 
areas support ca. $10 \%\left(\sim 0.8 \mathrm{Pg} \mathrm{C} \mathrm{yr}^{-1}\right)$ of the total global new production (Chavez \& Toggweiler 1995). The Humboldt Current (which runs northward along the western coast of South America) is extremely productive; $19.9 \mathrm{~g} \mathrm{C} \mathrm{m}^{-2} \mathrm{~d}^{-1}$ are fixed by photosynthesis in the south and central fishing areas, and $9.3 \mathrm{~g} \mathrm{C} \mathrm{m}^{-2} \mathrm{~d}^{-1}$ in the Antofagasta upwelling to the south (Daneri et al. 2000). Recent estimates suggest that the Humboldt Current produces 7 million tonnes in annual fish catch (Daneri et al. 2000).

In pelagic HNLC regions of the equatorial Pacific, picoplanktonic cyanobacteria such as Synechococcus and Prochlorococcus are the most abundant photosynthetic organisms in the water column (Chavez et al. 1991, Fogg 1995). Although no direct evidence exists to account for their success, their ability to alter cellular Fe quotas, their small size, and their ability to use high-affinity Fe-acquisition mechanisms may allow for their persistence in Fe-limited HNLC environments (Brand 1991, Wilhelm \& Trick 1994, 1995, Hutchins et al. 1999b). These studies, mostly in laboratory settings, suggest that these cyanobacteria assume an alternate physiology that allows them to persist when Fe availability may be growth limiting. In field studies, where HNLC environments have been fertilized with $\mathrm{Fe}$, a shift in species composition is usually observed, with large diatoms replacing small prokaryotic phototrophs such as Synechococcus (Coale et al. 1996, de Baar \& Boyd 2000).

In parallel to $\mathrm{Fe}$ fertilization studies, Fe 'removal' studies have evolved where the concentration of bioavailable $\mathrm{Fe}$ is reduced by the addition of a xenobiotic chelating agent. Desferrioxamine B (DFB, sold commercially as Desferal ${ }^{\circledR}$ ) is a commercially available aposiderophore produced by the terrestrial actinomycete Streptomyces pilosus (Winkelmann 1991). DFB has been demonstrated to effectively reduce the available Fe to most members of the phytoplankton community (Wells et al. 1994, Hutchins et al. 1999a, Wells 1999, Timmermans et al. 2001). However, some evidence suggests that a diatom isolate (Soria-Dengg \& Horstmann 1995, Hutchins et al. 1999a) and phytoplankton communities in the Subarctic Pacific (Maldonado \& Price 1999) can access at least small amounts of DFB-bound Fe (although probably not enough Fe to satisfy cellular requirements, Hutchins et al. 1999a). Also, Martinez et al. (2001) have recently demonstrated the production of desferrioxamine $\mathrm{G}$ (a close structural relative to DFB) by a marine Vibrio sp. isolated from an invertebrate larva, suggesting that there may also be natural sources of related compounds in marine systems.

We present a series of experiments designed to elucidate the in situ Fe status of the major groups of the natural phytoplankton community in a subtropical
Pacific HNLC upwelling region. In an attempt to infer the Fe-status of the population without perturbing it, we have combined the Fe addition and removal experiments, described above, to manipulate the concentration of bioavailable Fe both above and below ambient concentration. Moreover, we have done this in the presence of naturally occurring Fe-binding ligands using native phytoplankton populations. As such, we can observe the results of the control population in reference to both increases and decreases in Fe availability. Our overall goal was to distinguish between Fereplete (where growth is limited by something other than Fe), Fe-stressed (where growth is restricted by Fe availability but can be further constrained by lowering available Fe) and Fe-starved (where growth cannot be further restricted by more severe Fe-limitation) populations within these natural communities. The results confirm that phytoplankton in the Humboldt Current and Peruvian upwelling can experience Fe limitation, and demonstrate that the abundance and cellular physiology of different populations within the same phytoplankton community respond in distinct ways to alterations of Fe availability.

\section{MATERIALS AND METHODS}

Sample collection. Water samples for incubation experiments were collected off the coast of Peru in September 2000 (Fig. 1, for station characteristics see Table 1). Stations were chosen based on the concentration of dissolved Fe in surface waters. All stations had ambient concentrations $<100 \mathrm{pM}$, which we considered to represent Fe-limiting or near-limiting conditions. Surface seawater $(\sim 7 \mathrm{~m}$ depth) was collected with a clean surface pump system (Bruland et al. 2001) using an all PTFE Teflon ${ }^{\mathrm{TM}}$ diaphragm pump (Osmonics Bruiser ${ }^{\mathrm{TM}}$ ) and PFA Teflon ${ }^{\mathrm{TM}}$ tubing with a PVC 'fish' deployed off the side of the ship outside of the wake. Water was collected directly into a dedicated 501 acid-cleaned polyethylene carboy for homogenization. Once mixed, seawater was dispensed into $1.1 \mathrm{l}$ acid-cleaned polycarbonate bottles. All water sampling was carried out under class-100 clean conditions.

Manipulations of available Fe. Fe availability to phytoplankton in this study was decreased by the addition of DFB. Rue \& Bruland (1995) have estimated the conditional stability constant of Fe(III) with Desferal ${ }^{\circledR}$ to be $10^{16.5} \mathrm{M}^{-1}$ with respect to Fe(III)'. A $10 \mathrm{nM}$ addition of Desferal, if in equilibrium with Fe(III), would result in a ratio of [Fe(III)-Desferal] to [Fe(III)'] of approximately $10^{8.5}$ and result in extremely low equilibrium concentrations of Fe(III)'. Moreover, as discussed in previous work (Rue \& Bruland 1997), it is likely that photochemical activity will increase the dis- 


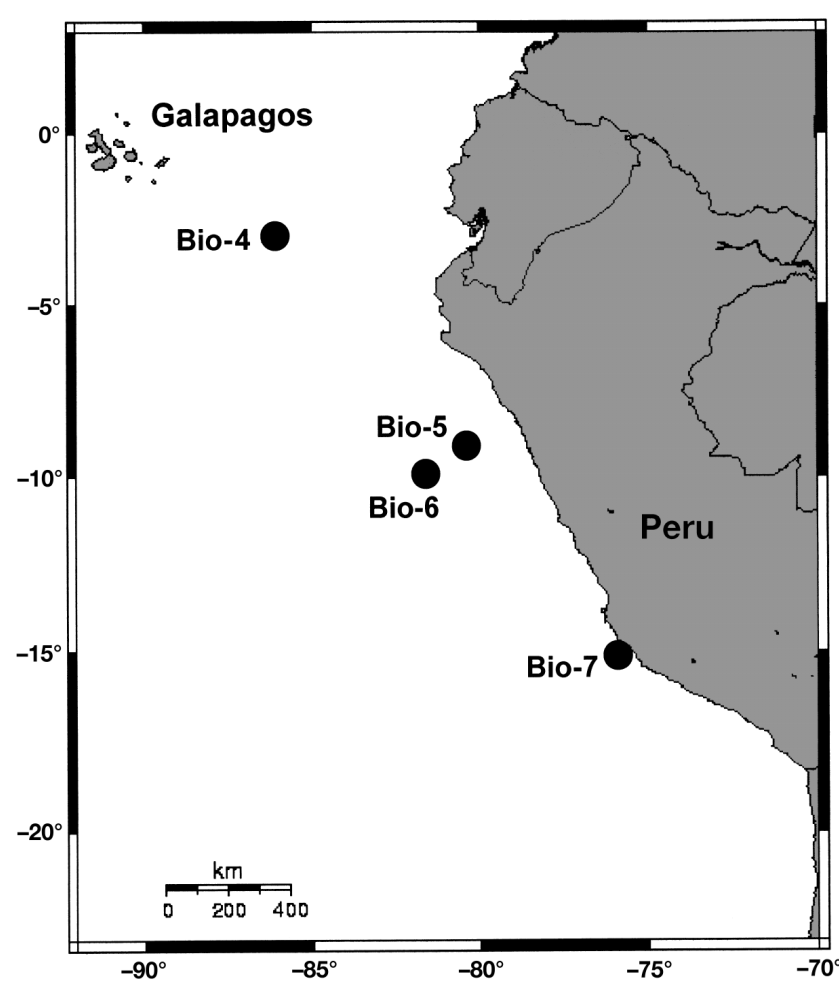

Fig. 1. Location of stations in the subtropical eastern Pacific Ocean

solution rates of naturally occurring Fe-ligand complexes, leading to an increased formation rate of photostable Fe-Desferal complexes (Barbeau et al. 2003).

DFB was purchased from the Sigma Chemical Company and dissolved into sterile, Chelex-100 treated water (Price et al. 1989) from a Millipore BioCell water purification system. Aliquots of the DFB stock were added to sample bottles to generate a replicate series of DFB concentrations of 1 to $10 \mathrm{nM}$ DFB. In parallel, $+\mathrm{Fe}$ bottles were amended with $\mathrm{FeCl}_{3}$ (dissolved in $0.01 \mathrm{M}$ Ultrex $\mathrm{HCl}$ ) to final concentrations ranging from 0.5 to $5.0 \mathrm{nM}$ of added Fe. In combination with control bottles (bottles with no DFB or Fe added), this resulted in concentrations of Fe ranging from $10 \mathrm{nM}<$ ambient (+10 nM DFB) to $5.0 \mathrm{nM}>$ ambient (+5.0 nM $\mathrm{Fe}$ ). Sealed bottles were placed in on-deck, flowing seawater incubators (temperature ranged from 16.3 to $20.3^{\circ} \mathrm{C}$ across stations) lined with a $3.2 \mathrm{~mm}$-thick sheet of spectrum-correcting blue Plexiglas ${ }^{\circledR}$ to simulate the light intensity and spectral quality of the $50 \%$ incident depth in the water column (Laws et al. 1990, Wells 1999). All subsampling occurred after sunset to reduce light-exposure effects, and to guarantee a full solar day exposure per $24 \mathrm{~h}$ period.

For the first station, subsamples were collected daily (up to $96 \mathrm{~h}$ ) from the bottles under class-100 conditions. For subsequent stations samples were collected only at the $72 \mathrm{~h}$ time-point in order to reduce the potential for contamination during subsampling and the influence of bottle effects that were observed after this time-point. Total chlorophyll was determined from $50 \mathrm{ml}$ samples collected on $0.2 \mu \mathrm{m}$ pore-size polycarbonate filters (Osmonics) after extraction $(\sim 24 \mathrm{~h})$ in $90 \%$ acetone. Chlorophyll $(>0.2 \mu \mathrm{m}$ [total] and $>5.0 \mu \mathrm{m})$ was quantified with a Turner designs 10-AU fluorometer using the non-acidification protocol of Welschmeyer (1994).

Flow cytometry. Phytoplankton communities were analyzed immediately upon sampling (without initial preservation) using a Becton Dickinson FACSCalibur flow cytometer (which handles particles up to $180 \mu \mathrm{m}$ ) equipped with a $15 \mathrm{~mW}$ argon laser (488 nm excitation) and CellQuest analysis software. To normalize the spectrum of cell responses, the software was calibrated using 1, 2, 4, 10, and $16 \mu \mathrm{m}$ non-fluorescent beads for cell-size based calibration, $10 \mu \mathrm{m}$ fluorescent beads and lab phytoplankton cultures to standardized size and fluorescence corresponding to chlorophyll (660 to $700 \mathrm{~nm}$ ) and phycoerythrin (530 to $630 \mathrm{~nm}$ ). Fluorescence and cell light-scattering properties were used in a 2D analysis to distinguish phytoplankton groups (Frankel et al. 1990).

Fast repetition rate fluorometry. Photosynthetic efficiency (the ratio of variable fluorescence to maximal fluorescence, $F_{\mathrm{v}}: F_{\mathrm{m}}$ ) was measured by analyzing $50 \mathrm{ml}$ aliquots of samples in the dark chamber of the FAST $^{\text {tracka }}$ fast repetition rate fluorometer (FRRF; Chelsea Instruments). All samples were analyzed $\sim 2 \mathrm{~h}$ after local sunset to avoid diel periodicity effects, and were dark-adapted at room temperature for at least 15 min prior to analysis. Data were analyzed using the FAST $^{\text {tracka }}$ FRRF post-processing program version 1.4 (Chelsea Instruments).

Table 1. Station characteristics. Nutrient concentrations are in $\mu \mathrm{M}$ except for Fe, which is in $\mathrm{nM}$

\begin{tabular}{|c|c|c|c|c|c|c|c|c|}
\hline \multirow[t]{2}{*}{ Stn } & \multirow[t]{2}{*}{ Location } & \multirow{2}{*}{$\begin{array}{l}\text { Total chl a } \\
\quad\left(\mu \mathrm{g}^{-1}\right)\end{array}$} & \multirow{2}{*}{$\begin{array}{l}\text { Salinity } \\
\text { (psu) }\end{array}$} & \multirow{2}{*}{$\begin{array}{c}\text { Temperature } \\
\left({ }^{\circ} \mathrm{C}\right)\end{array}$} & \multicolumn{4}{|c|}{ Nutrient concentrations } \\
\hline & & & & & $\mathrm{NO}_{3}^{-}+\mathrm{NO}_{2}^{-}$ & $\mathrm{PO}_{4}$ & $\mathrm{SiO}_{2}$ & $\mathrm{Fe}$ \\
\hline Bio-4 & $86.30^{\circ} \mathrm{W}, 3.10^{\circ} \mathrm{S}$ & 1.5 & 35.0 & 19.6 & 24 & 1.5 & 15 & 0.06 \\
\hline Bio-5 & $80.47^{\circ} \mathrm{W}, 9.16^{\circ} \mathrm{S}$ & 1.3 & 35.1 & 18.3 & 17.3 & 1.16 & 6.9 & 0.1 \\
\hline Bio-6 & $81.57^{\circ} \mathrm{W}, 9.81^{\circ} \mathrm{S}$ & 0.7 & 35.2 & 18.8 & $14-15$ & $1.2-1.3$ & 6.0 & 0.1 \\
\hline Bio-7 & $76.02^{\circ} \mathrm{W}, 15.23^{\circ} \mathrm{S}$ & 1.2 & 34.8 & 15.8 & $11-12$ & 1.5 & $10-12$ & 0.08 \\
\hline
\end{tabular}


Nutrient and Fe measurements. Combined nitrogen $\left(\mathrm{NO}_{3}{ }^{-}+\mathrm{NO}_{2}{ }^{-}\right)$, phosphate and silicic acid concentrations were measured on a Lachat Quick Chem $8000^{\mathrm{TM}}$ Flow Injection Analysis system using standard methods (Parsons et al. 1984). Total dissolved Fe was measured electrochemically on board the ship by competitive ligand equilibration (CLE), followed by adsorptive cathodic stripping voltammetry (ACSV) with salicylaldoxime (SA) as the competing ligand (Rue \& Bruland 1995). Dissolved $(<0.2 \mu \mathrm{m}) \mathrm{Fe}$ was measured by acidifying the sample ( $\mathrm{pH} 1.7)$, followed by briefly microwaving and, once cooled to room temperature, applying the ACSV technique (Bruland et al. 2001).

Fe assimilation measurements. To demonstrate that DFB inhibited Fe uptake in the natural microbial community, we carried out an Fe assimilation experiment at Bio-7. Assimilation rates were monitored through the addition of ${ }^{55} \mathrm{Fe}$ (as ${ }^{55} \mathrm{FeCl}_{3}$ in $0.5 \mathrm{M} \mathrm{HCl}$, ca. $42 \mathrm{mCi} \mathrm{mg}^{-1}$, from $\mathrm{New}$ England Nuclear) to water samples. Cleanly collected water was dispensed into acid-clean 1.21 polycarbonate bottles and amended with ${ }^{55} \mathrm{Fe}$ to a final concentration of $2 \mathrm{nM}$. Samples were allowed to incubate for $48 \mathrm{~h}$ in the ondeck incubators, and were terminated by the collection of cells onto $0.2,1.0$ or $8.0 \mu \mathrm{m}$ filters, with the removal of extracellular ${ }^{55} \mathrm{Fe}$ with the titaniumcitrate-EDTA wash (3 min total exposure) of Hudson \& Morel (1989). Incorporated Fe was subsequently determined by scintillation counting and normalized to the volume filtered for each size class.

\section{RESULTS}

\section{Station description}

The 4 stations occupied during these experiments all displayed classic HNLC characteristics (Table 1). High concentrations of $\mathrm{NO}_{3}^{-}+\mathrm{NO}_{2}^{-}(11$ to $24 \mu \mathrm{M})$, phosphate $(1.2$ to $1.5 \mu \mathrm{M})$ and silicate (6 to $15 \mu \mathrm{M})$ were accompanied by low concentrations of dissolved Fe (60 to $100 \mathrm{pM}$ ) and chlorophyll (0.7 to $1.5 \mu \mathrm{g} \mathrm{l^{-1 }}$.

\section{Total community response to Fe additions and removal}

Increases in total Fe concentrations lead to dramatic increases in phytoplankton biomass, as estimated by total chlorophyll (Fig. 2). Averaged across all stations, the total chlorophyll in the $+\mathrm{Fe}$ bottles was $218 \%$ $( \pm 62 \%)$ of the concentrations reached in the control bottles. Similarly, the +DFB bottles showed depressions in total chlorophyll $(47 \pm 15 \%)$. These results imply that both the addition and removal of Fe led to changes in the physiology or abundance of the cells, in the overall phytoplankton community structure, or in
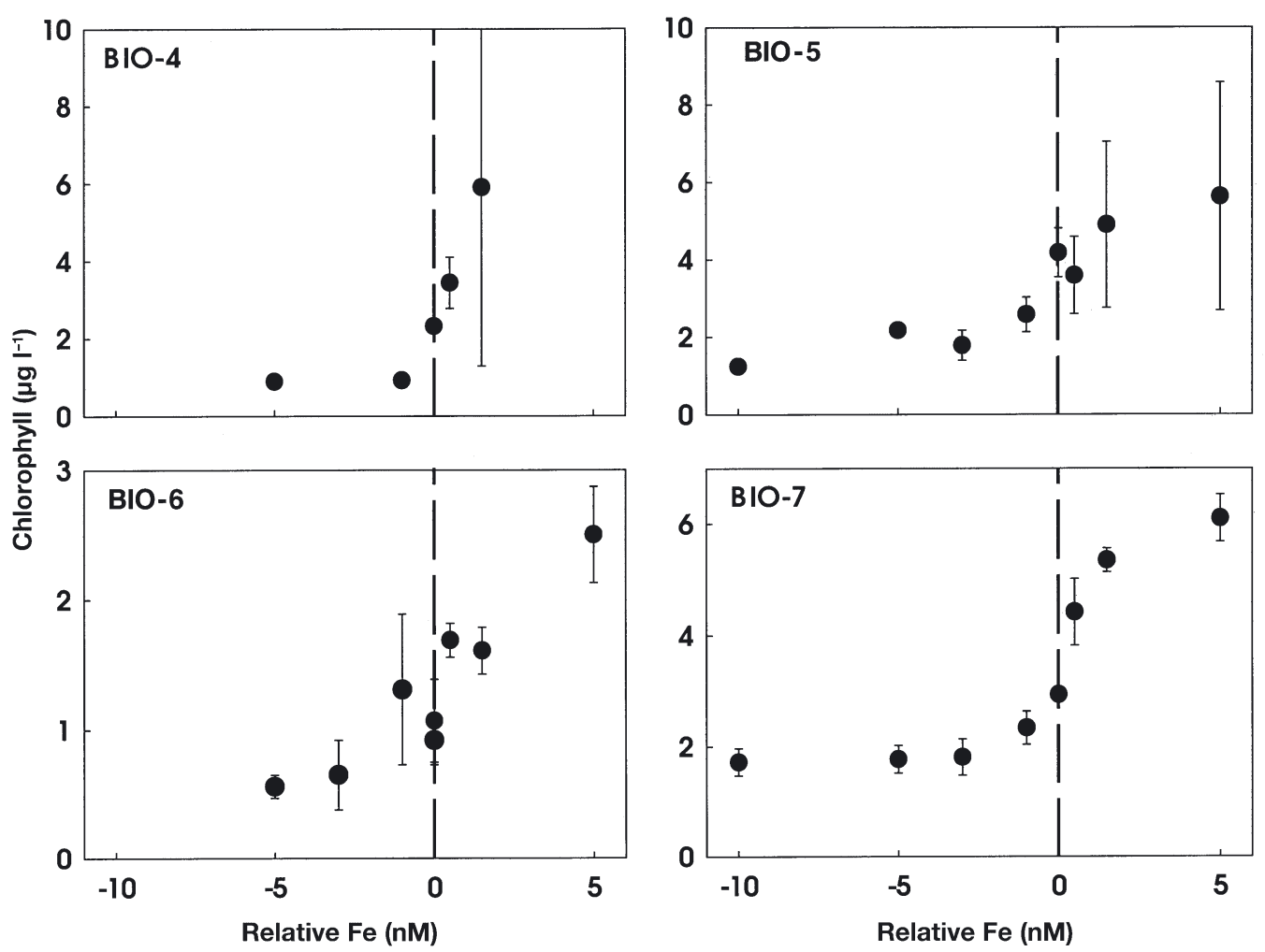

Fig. 2. Phytoplankton biomass in on-deck incubations as estimated by total chl a $(>0.2 \mu \mathrm{m})$ after a $72 \mathrm{~h}$ incubation. Results are the means \pm error of either duplicate (Bio- $4, \pm$ range) or triplicate (Bio-5, Bio-6, Bio-7, \pm SD) incubations and are presented in respect to the ambient concentration (dashed line, where relative $\mathrm{Fe}=0$ ) 
all of these parameters. Changes in the physiology of the phytoplankton are seen in the $F_{\mathrm{v}}: F_{\mathrm{m}}$ data from Fig. 3. Photosynthetic efficiency was increased in all samples (113 to $210 \%$ of control values) where Fe was added, and remained low or decreased slightly (83 to $103 \%$ of control values) when DFB was added. These results suggest that the entire phytoplankton community at each station existed in a state of Fe-stress and that while Fe addition alleviated constraints on growth, the community could be pushed into further physiological stress by the addition of DFB. Interestingly, it does not appear that the Fe requirements of the phytoplankton communities were saturated by our additions, as neither the $F_{\mathrm{v}}: F_{\mathrm{m}}$ nor the chlorophyll values plateau in our + Fe treatments.

Nutrient assimilation data from 3 of the stations (measurements were not made at Bio-4) also suggest that availability of $\mathrm{Fe}$ constrained the assimilation of macronutrients by plankton populations at Stns Bio-5 and Bio-6 (Fig. 4). The residual combined nitrogen $\left(\mathrm{NO}_{3}{ }^{-}\right.$ $+\mathrm{NO}_{2}^{-}$) concentration in $+\mathrm{Fe}$ bottles at Stn Bio-5 was significantly less (paired $\underline{t}$-test, $\mathrm{p}<0.05$ ) than the unamended control for both the 1.5 and $5 \mathrm{nM}$ treatments. More striking were the results of the DFB additions at Stns Bio-5 and Bio-6 that resulted in a repression of drawdown of these nutrients. Considering the Fe and DFB addition data together, the overall trend supports the role of Fe as a limiting agent at these 2 stations.

\section{Response of specific groups to alterations in Fe availability}

To examine how alterations in Fe availability may affect population diversity, we examined the community composition by flow cytometry (Fig. 5). Fig. 5 demonstrates the predicted response of different phytoplankton populations that are Fe-replete (Fig. 5Ai), Fe-stressed (Fig. 5Aii) or Fe-starved (Fig. 5Aiii) (discussed below). Of the 8 separate populations that could be identified with the flow cytometer (based on differences in cell size, density and pigment composition), 3 populations of larger cells were not considered for analysis due to low $(<200$ $\mathrm{ml}^{-1}$ ) cell densities which would cause statistical uncertainty. The 5 remaining populations represented cyanobacteria, picoeukaryotes (2 to $5 \mu \mathrm{m})$, small eukaryotes (5 to $10 \mu \mathrm{m}$ ), eukaryotes (10 to $20 \mu \mathrm{m}$ ) and large eukaryotes $(>20 \mu \mathrm{m})$. Large particles that demonstrated no autofluorescence were also not considered. While there are inherit limitations to these groupings (see 'Discussion'), they do provide an operational approach to rapidly examining community structure.

Results from Stn Bio-4 provided clear evidence that different populations were responding differently to alterations in Fe-availability (Fig. 5). The 3 largest eukaryotic groups all demonstrated increases in cell density with the addition of $\mathrm{Fe}$, but no significant alterations in cell abundance or relative chlorophyll cell ${ }^{-1}$
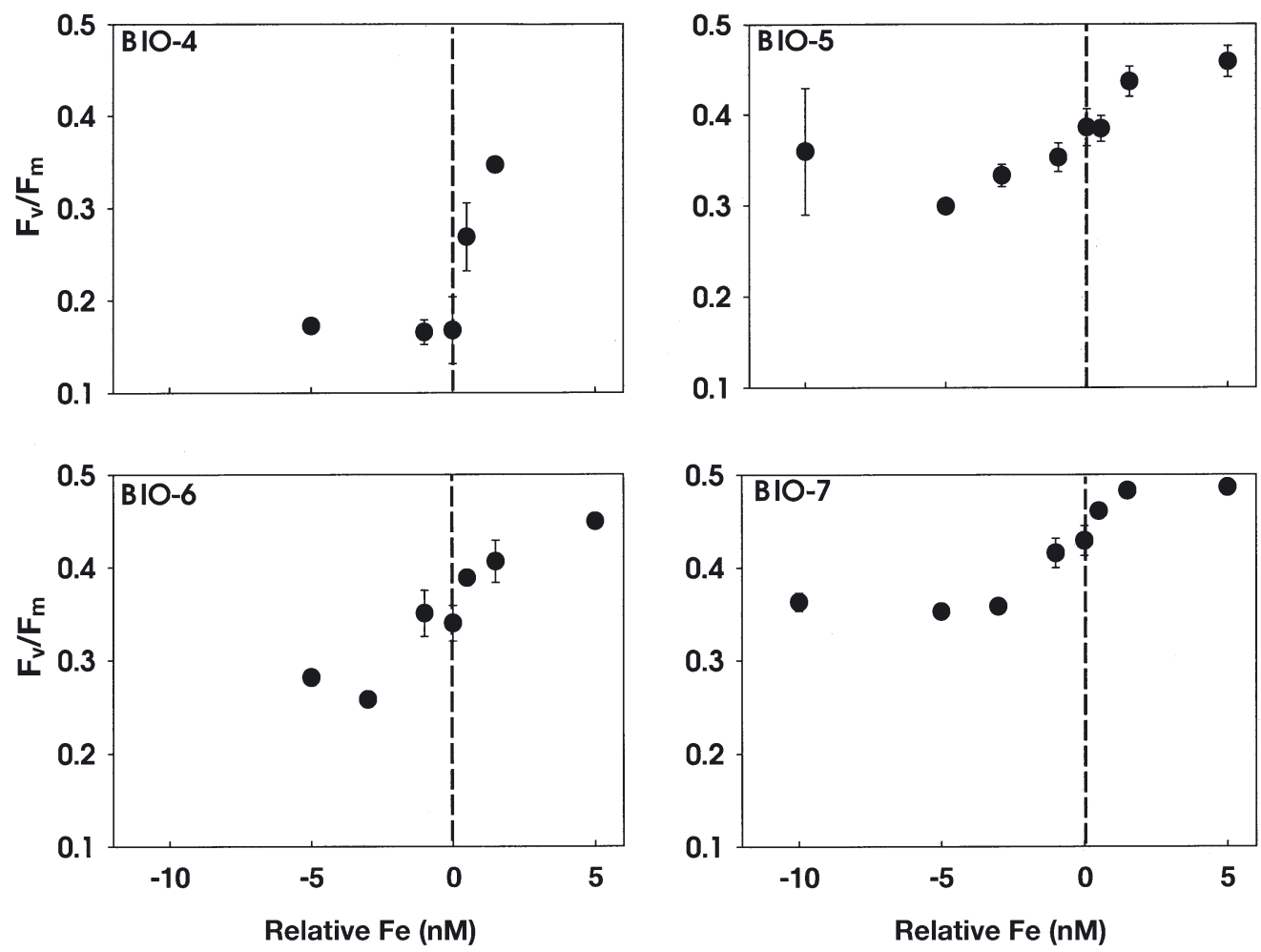

Fig. 3. Photosynthetic efficiency (ratio of variable fluorescence to maximal fluorescence, $\left.F_{\mathrm{v}}: F_{\mathrm{m}}\right)$ of populations from on-deck incubations (as per Fig. 2) as estimated by fast repetition rate fluorometry after $72 \mathrm{~h}$ incubation 

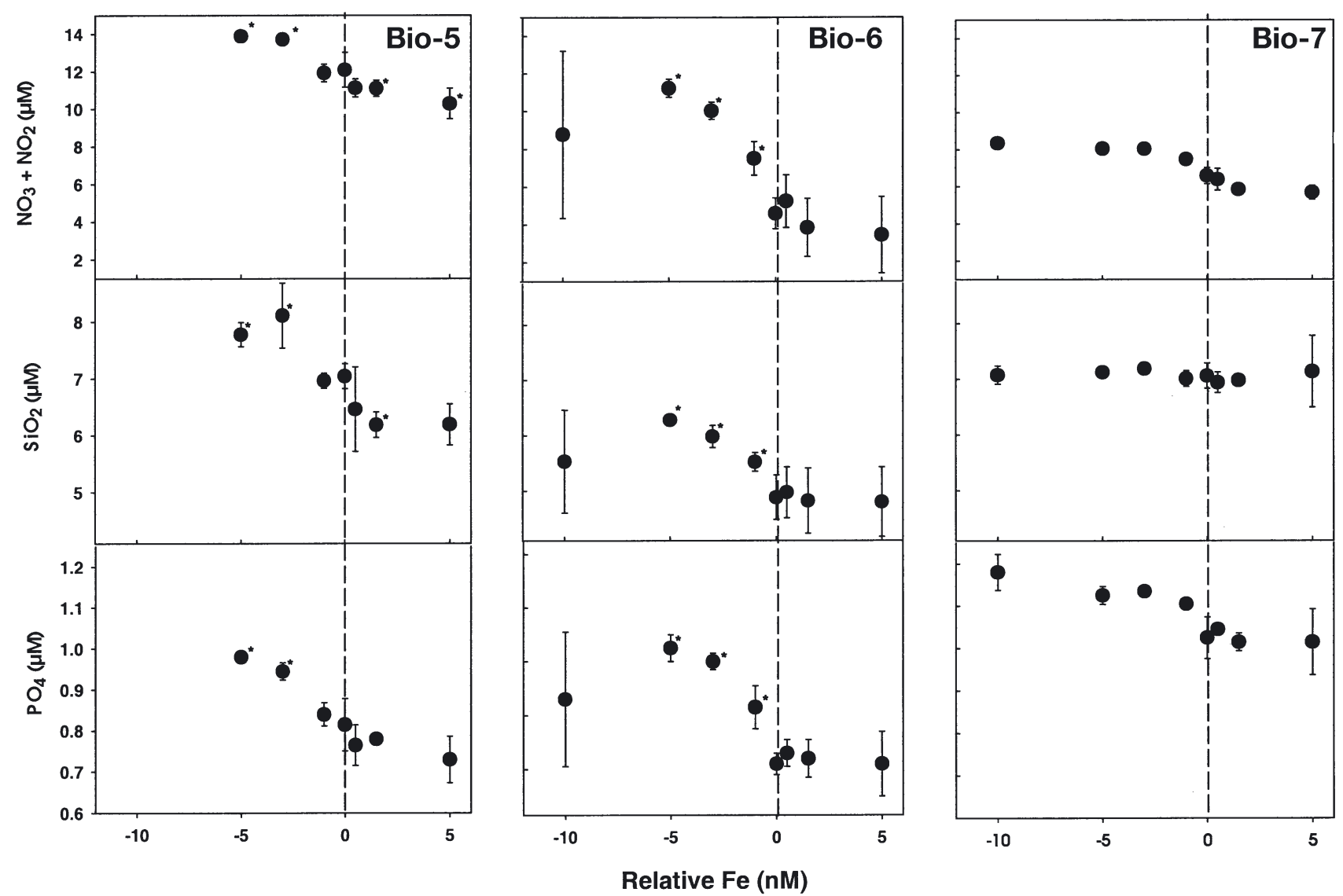

Fig. 4. Nutrient concentrations in samples at the termination of the incubations after $72 \mathrm{~h}$ incubation. Results are means $( \pm$ SD) of triplicate incubations and presented in respect to the ambient concentration (dashed line, where relative Fe $=0$ ). Nutrient samples for Stn Bio-4 were contaminated and thus are not presented. Samples statistically different from the control ( $\mathrm{p}<0.05)$ are denoted by an asterisk. The significance of some treatments at greater p-values is discussed in the section 'Discussion'

with the addition of DFB. While the cyanobacteria also demonstrated an increase in cell density in the $+\mathrm{Fe}$ treatments, additions of DFB led to suppression in relative cell density. Perhaps the most striking response was that of the picoeukaryotic phytoplankton, which showed no change in the Fe addition experiments but increased markedly in the +DFB treatments. DFB addition did lead to decreases in the estimates of the relative chlorophyll cell ${ }^{-1}$ in all these populations in the Stn Bio-4 incubations, including the picoeukaryotes (Fig. 6). This change in the picoeukaryotes was also accompanied by a change in the mean cell-size of this population, which decreased over a 4 -fold range from the $+\mathrm{Fe}$ to the + DFB bottles (Fig. 7). Other phytoplankton groups showed no dramatic changes in cell size among treatments.

\section{Influence of DFB on ${ }^{55} \mathrm{Fe}$ uptake}

Since some data suggest that DFB-bound Fe is available to phytoplankton (e.g. Maldonado \& Price 1999), we felt it prudent to demonstrate that DFB inhibited Fe uptake in this region. Increasing concentrations of DFB added to bottles effectively limited the Fe uptake ability of phytoplankton in each of 3 different size classes ( $>0.2$, $>1.0,>8.0 \mu \mathrm{m}$ ) in our uptake experiments (Fig. 8). In all size classes, rates of assimilation decreased $\sim 3$-fold at concentrations higher than $5 \mathrm{nM}$. In previous studies the availability of ${ }^{55} \mathrm{Fe}-\mathrm{DFB}$ to a marine plankton was demonstrated after only $4 \mathrm{~h}$ (Maldonado \& Price 1999, Maldonado \& Price 2001); as such, our $48 \mathrm{~h}$ incubation period confirms that the planktonic community had a reduced ability to assimilate ${ }^{55} \mathrm{Fe}-\mathrm{DFB}$, and was not able to activate any potential high-affinity transport systems (e.g. siderophore-mediated pathways) or enzymes (e.g. surface reductases) that would allow the cells to assimilate the Fe from the DFB. That said, it should also be noted that longer incubation periods (required for time consistency with the growouts) may lead to underestimates of Fe assimilation (e.g. due to isotopic dilution, biphasic assimilation, etc.). We have attempted to decrease the impact of this on the data by expressing the results as total ${ }^{55} \mathrm{Fe}$-assimilated over the incubation period. 

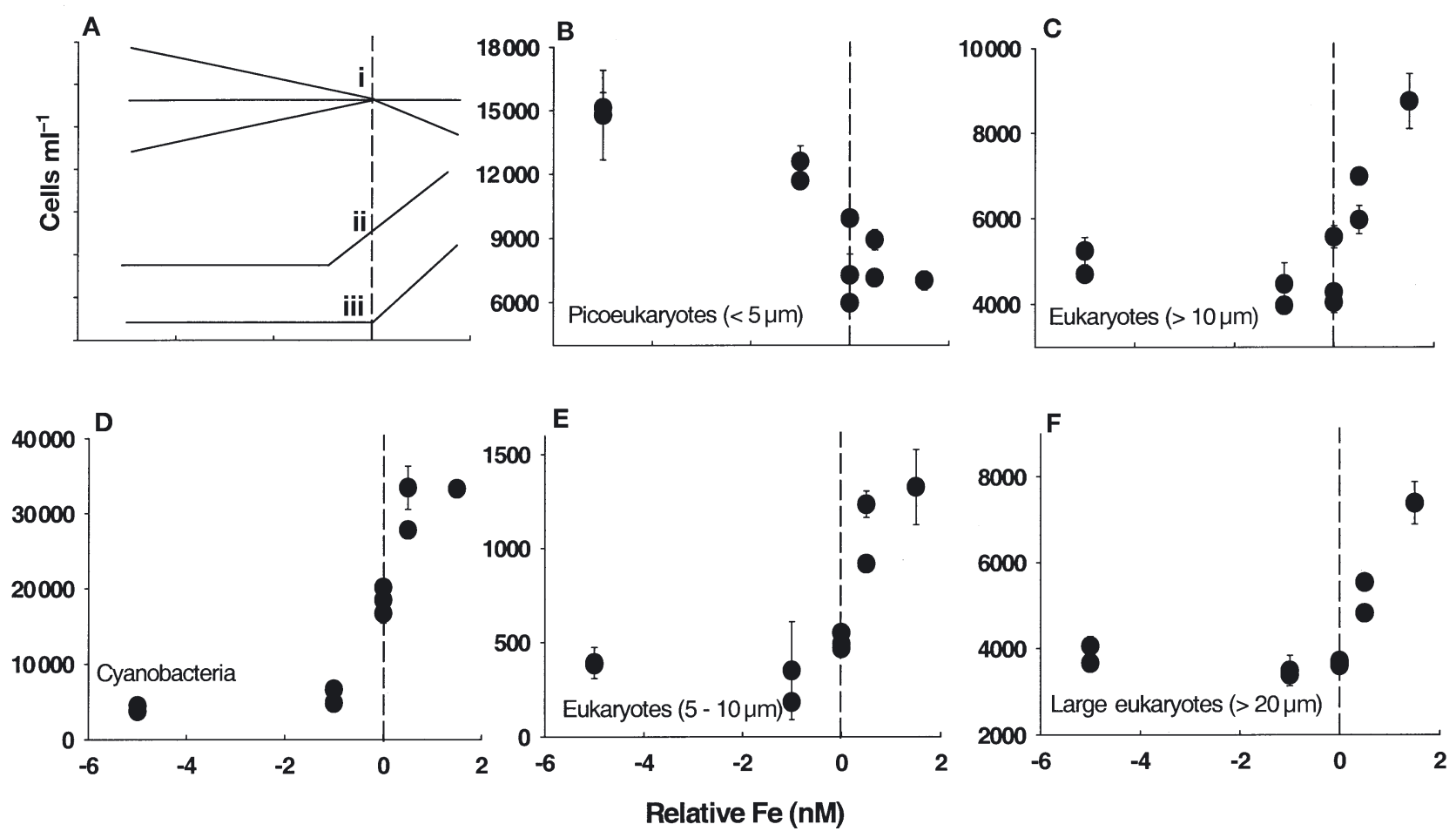

Fig. 5. Cell density of different groups in on-deck incubations from Stn Bio-4 (means \pm range) as estimated by flow cytometry after $72 \mathrm{~h}$ (including a 3rd control bottle). (A) Predicted response of populations when (i) Fe-sufficient, (ii) Fe-stressed, and (iii) Fe starved. These hypothetical responses were predicted a priori to account for all potential responses (B to F). The 5 major groups of plankton are presented in respect to the ambient concentration (dashed line, where relative $\mathrm{Fe}=0$ )

\section{DISCUSSION}

Fe addition experiments have demonstrated that production by phytoplankton along the western coast of Peru can be limited by the availability of Fe (Hutchins et al. 2002), but these experiments did not elucidate the degree to which these populations may be limited. The basic approach of our study was to infer the in situ status of the phytoplankton community from the impacts of both increases and decreases in $\mathrm{Fe}$ availability. This process allows for a determination of the status of the in situ community as an interpolation of the data.

There are several important conclusions that can be drawn from this work. Firstly, this study confirms the findings of Hutchins et al. (2002) that the phytoplankton community in the Peruvian upwelling can be Felimited in a manner analogous to previously studied communities in the coastal upwelling systems of California (Hutchins \& Bruland 1998, Bruland et al. 2001). Secondly, this work confirms that DFB can be used to reduce the biological availability of Fe to the total community of phytoplankton in bulk analyses. Finally, it demonstrates how a xenosiderophore can be employed in conjunction with Fe addition experiments to distinguish between populations of cells that are Fe- starved, -stressed and -replete. The use of shipboard flow cytometry in conjunction with in situ dissolved Fe measurements also allows us to draw 2 important conclusions regarding phytoplankton physiology. Most phytoplankton demonstrated dramatic changes in chlorophyll cell ${ }^{-1}$ with changes in bioavailable Fe, and picoeukaryotes became more successful when Fe levels were decreased with DFB, most likely via miniaturization. These conclusions are discussed in more detail below.

\section{Physiological measurements of whole community response}

The most common analysis of phytoplankton response to fertilization in both bottle amendment (Martin \& Gordon 1988, Hutchins \& Bruland 1998) and mesoscale fertilization (Coale et al. 1996, Boyd et al. 2000) experiments has been a comparison of the total chlorophyll in the control vs. treatment populations. Although growth rate is strictly defined as the changes in cell number over time (Madigan et al. 2000), water column or sample chlorophyll is often used as a proxy for autotrophic community biomass. In this study, we demonstrate that chlorophyll concentrations increase 
Fig. 6. Relative chl a cell ${ }^{-1}$ in on-deck incubations from Stn Bio-4 (means \pm range) as estimated by flow cytometry after $72 \mathrm{~h}$ (including a 3rd controlbottle). The 5 major groups of plankton are presented in respect to the ambient concentration (dashed line, where relative $\mathrm{Fe}=0$ )
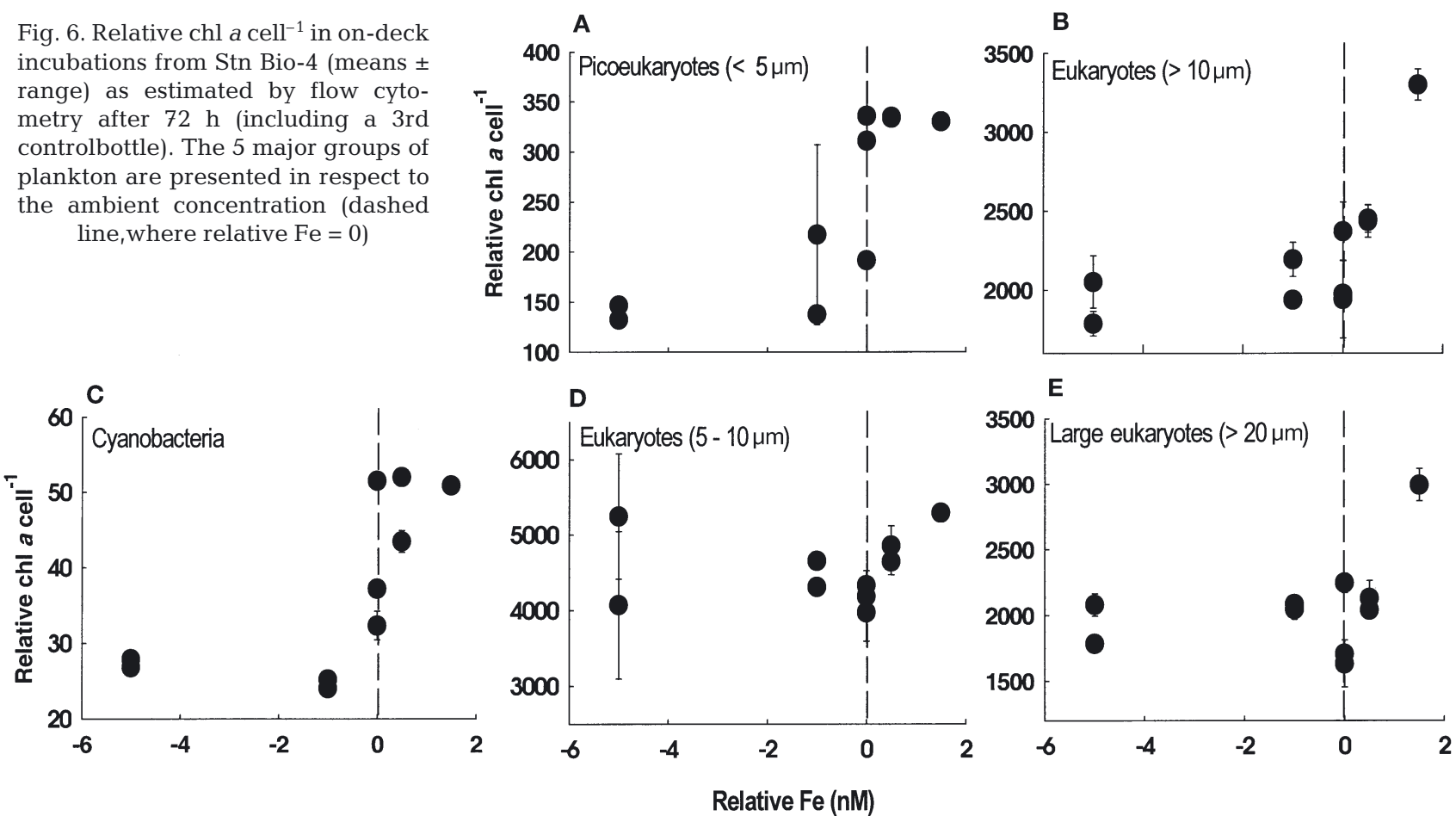

in all the added Fe amendments, and decrease in all the added DFB amendments, relative to our unamended control bottles. One parameter that is often overlooked is the changes that can occur in individual

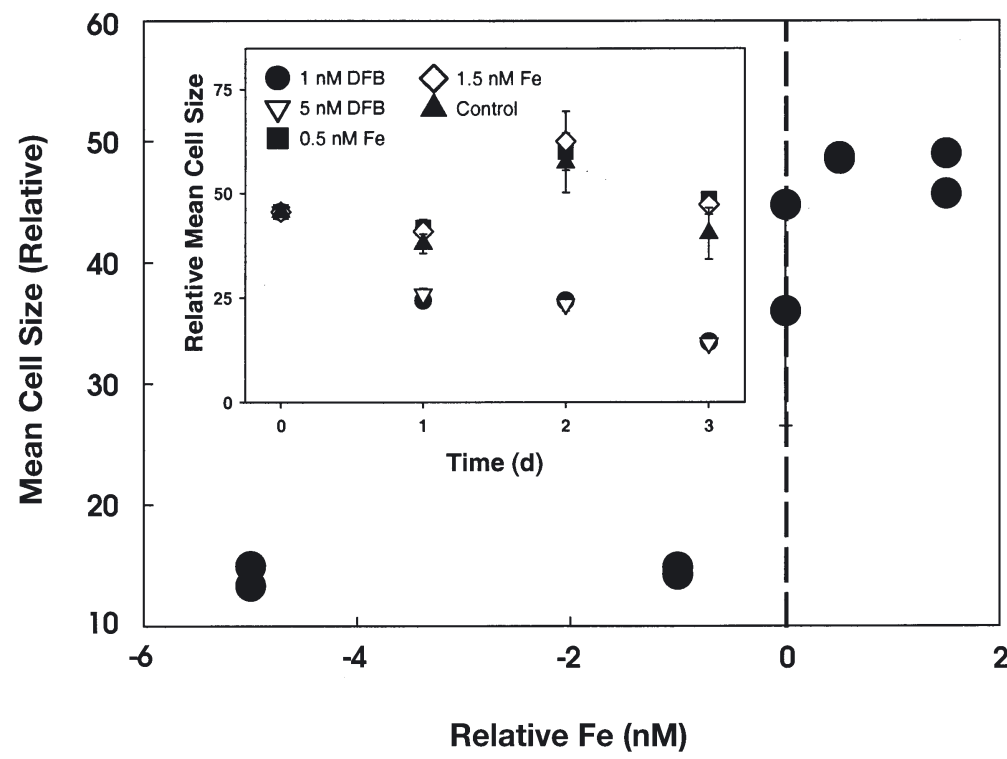

Fig. 7. Mean cell size of picoeukaryotes in Stn Bio-4 samples as estimated by flow cytometry after $72 \mathrm{~h}$. Mean size of the population changed 4 -fold over the range of experimental $\mathrm{Fe}$ availabilities. Dashed line indicates ambient concentration where relative $\mathrm{Fe}=0$. Inset shows daily estimates of picoeukaryotic size collected every $24 \mathrm{~h}$ over the $72 \mathrm{~h}$ period of the Bio- 4 experiment. DFB: the xenobiotic chelating agent Desferrioxamine B cells within the community that may skew the results of 'bulk' measurements. It has been shown in several laboratory studies that populations of both cyanobacteria (Wilhelm \& Trick 1995, Wilhelm et al. 1996) and eukaryotic phytoplankton (Muggli et al. 1996) decrease their relative chlorophyll cell $^{-1}$ when they are moved from Fereplete to Fe-deficient culture conditions. In cyanobacteria, this change in chlorophyll cell ${ }^{-1}$ can be 2-fold or greater (Wilhelm et al. 1996). For eukaryotes, the diatom Actinocyclus sp. changes chlorophyll cell ${ }^{-1} \sim 1.9$ - to 3.2-fold (Muggli et al. 1996), while the diatom Phaeodactylum tricornutum decreases chlorophyll cell volume $^{-1}$ by $50 \%$ under Fe-deficient conditions (Kudo et al. 2000). In the current study, results from the flow cytometric analyses clearly demonstrate that the chlorophyll cell ${ }^{-1}$ in the individual groups of phytoplankton was altered by changes in $\mathrm{Fe}$ availability, with cells in $+\mathrm{Fe}$ conditions containing 25 to $200 \%$ more chlorophyll than cells in the +DFB bottles. However, the flow cytometry data confirm that alterations in cell abundance for each of these populations also occurred (although in the case of picoeukaryotes, not as would have been predicted). Taken together, the results suggest that while bulk chlorophyll 


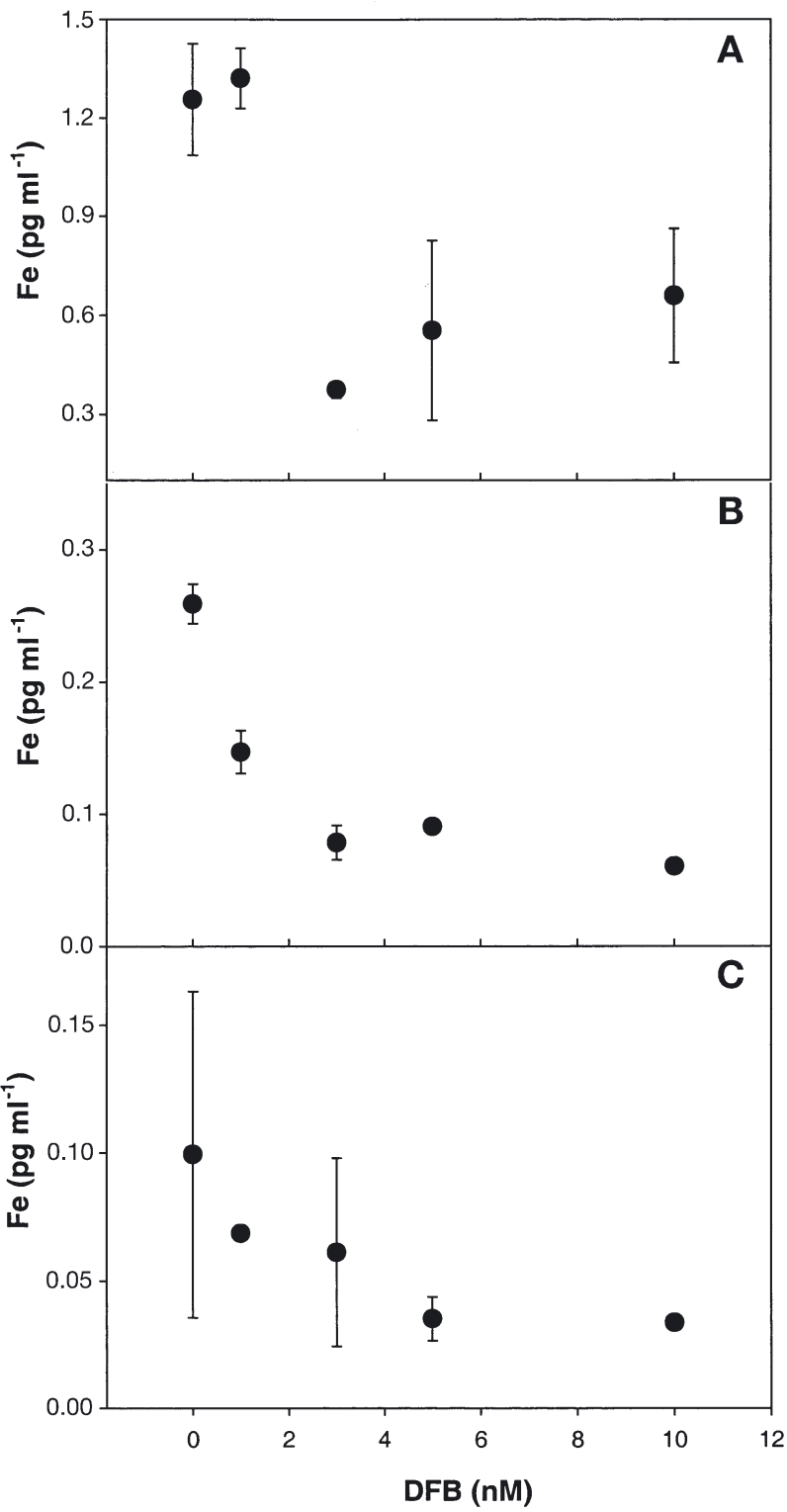

Fig. 8. Fe uptake (as ${ }^{55} \mathrm{Fe}$ ) across increasing concentrations of Desferrioxamine B (DFB) at Bio-7 after $48 \mathrm{~h}$. Mean estimates ( \pm range, $\mathrm{n}=2$ ). (A) $>0.2 \mu \mathrm{m}$ fraction. $(\mathrm{B})>1.0 \mu \mathrm{m}$ fraction. (C) $>8.0 \mu \mathrm{m}$ fraction

measurements remain a valid method for the determination of bulk effects on phytoplankton populations, alterations at the cell level may exaggerate these results and other factors such as light and $\mathrm{N}$-availability may further exacerbate the differences.

One of the best indicators of the status of an entire phytoplankton community may be the photosynthetic efficiency (Behrenfeld et al. 1996). As with the total chlorophyll, the $F_{\mathrm{v}}: F_{\mathrm{m}}$ increased (to as much as $200 \%$ of the control) with increasing Fe availability. In incubations carried out at Stns Bio-5, Bio-6 and Bio- 7 these increases were predictably hyperbolic with changes in
Fe concentration. Increases in $F_{\mathrm{v}}: F_{\mathrm{m}}$ at Stn Bio-4 also occurred, but due to the limited number of treatments the resolution of the relationship of the change to $\mathrm{Fe}$ availability was markedly reduced. Overall these results suggest that cellular physiology was limited at the photosynthetic level (at least in part) due to the availability of Fe.

\section{Distinguishing between Fe-replete, Fe-stressed and Fe-starved populations}

The most significant result from this study is that it provides us with a novel approach to gauge the in situ status of the natural phytoplankton population in terms of Fe availability. In their study of the California HNLC coastal upwelling, Hutchins et al. (1998) described 4 stages of Fe-limitation for an entire community. This classification was based primarily on $\mathrm{H}_{2} \mathrm{SiO}_{3}: \mathrm{NO}_{3}$ drawdown ratios and permitted the identification of 4 distinct classifications for surface waters in the region, ranging from Fe-replete to severely Fe-limited. In our approach, we are not yet able to quantitatively characterize the degree of Fe-limitation of the entire population. However, while there are obvious concerns with bottle effects in on-deck amendment experiments and effects of changes of cellular physiology, the results achieved in this study clearly show that there is at least an overall effect of Fe availability on the populations, and that the phytoplankton in these regions are in a state of Fe-stress

Diatoms have most consistently been the organisms that proliferate in both on-deck (Martin \& Gordon 1988, Hutchins et al. 1998) and mesoscale Fe addition (Coale et al. 1996, Boyd et al. 2000) experiments. In the Bio-4 incubations, eukaryotic cells $>5 \mu \mathrm{m}$ increased 1.5- to 2.5-fold in abundance in the +Fe treatments. While the abundance of cells in each of these populations changed significantly, the contribution to total chlorophyll remained relatively static for each group except the 5 to $10 \mu \mathrm{m}$ cells. Cyanobacteria also increased in both abundance ( 2.5-fold) and contribution to total chlorophyll (from a low of $0.5 \%$ to a high of $>4.0 \%$ ) in the $+\mathrm{Fe}$ bottles. However, unlike the larger eukaryotes, these cells demonstrated decreases in both abundance and contribution to total chlorophyll with the addition of DFB. Cyanobacteria have been demonstrated to produce siderophores during periods of $\mathrm{Fe}$ stress (Wilhelm \& Trick 1994, Wilhelm 1995) and to use these compounds to increase their Fe-assimilation during these periods (Trick \& Wilhelm 1995, Wilhelm et al. 1998). It was therefore hypothesized that this population should more effectively assimilate Fe from the DFB treatments due to a ligand-ligand exchange of $\mathrm{Fe}$ (between the DFB and the siderophores). However, as 
with the previous work of Wells et al. (1994), the current study suggests that Fe complexed to this xenosiderophore (DFB) is not available to Synechococcus spp. from this region. The results here also suggest that the cyanobacterial populations in this region are Festressed, but not Fe-starved, as the addition of DFB could force them into a state of greater limitation. This is in contrast to the 3 eukaryotic populations, which demonstrated an Fe-starved response to our treatments.

The picoeukaryotic organisms present the most striking results in this study. In HNLC regimes of the Southern Ocean, Boyd et al. (2000) found that picoeukaryotes were a dominant component of the system, and initially began to proliferate upon addition of Fe. However, after several days these cells decreased in abundance in the fertilized patch and were replaced by larger eukaryotic phytoplankton. Given the temporal resolution of our study, we were unable to detect any initial proliferation by the picoeukaryotes in the $+\mathrm{Fe}$ treatments. Surprisingly though, the picoeukaryotes' abundance in the +DFB bottles suggests the cells were able to proliferate under these conditions. However, if one examines the chlorophyll cell ${ }^{-1}$ and mean cell size data for this population across the range of treatments, it demonstrates that there was a marked decrease in both parameters. While there is a possibility that changes in Fe availability alter the competitive interactions between picoeukaryotes and the larger eukaryotes for macronutrients (e.g. $\mathrm{NO}_{3}{ }^{-}$), distinct physiological changes in the picoeukaryotes suggest that, in the case of DFB additions, the increase in cell abundance is a direct consequence of decreased Fe-availability. Although the picoeukaryotic phytoplankton appear to at best assimilate the DFB chelated $\mathrm{Fe}$ at a reduced rate (Fig. 8), these cells can alter their physiology (chlorophyll quota and apparently cellular Fe quota) to maintain their growth rate.

Responses to nutrient limitation by aquatic organisms are numerous. In the case of $\mathrm{Fe}$, research has commonly focused on changes in cell quota (Sunda et al. 1991, Wilhelm 1995) or the activation of highaffinity transporters (Wilhelm \& Trick 1994) as the mechanism by which cells compensate for nutrient limitation. One classic response to nutrient stress that is often overlooked in the case of Fe is changes to cell size. Microbial miniaturization has been shown to occur during periods of stress to increase the surface to volume ratio of cells (Morita 1975). This phenomenon has been observed in diatom communities where significant reductions in volumes of Nitzschia occurred in the California HNLC system (Hutchins et al. 1998). In theory, this increases the amount of surface receptor a cell has (a function of the total surface area) in respect to the requirement of the cell for the nutrient element (an approximate function of the cell volume). As such, individual cells can increase their ability to scavenge limiting nutrients from the environment without expending energy on transport systems (Chisholm 1992).

In laboratory studies, Fe-stressed Anacystis nidulans R2 (a Synechococcus sp.) decreases its cell size to between $1 / 2$ and $1 / 3$ of the length of Fe-replete cells (Sherman \& Sherman 1983). The filamentous cyanobacterium Anabaena flos-aquae carries out similar size changes as well as pronounced changes in filament coiling when maintained in an Fe-deficient medium (Gorham et al. 1964). In this particular study, the picoeukaryotic community decreased $\sim 4$-fold in size. This would result in a proportionate change in the surface area to volume ratio (given that the surface area to volume ratio is altered as $6 / d$, where $d$ is the diameter of the cell). It is important to point out, though, that there is an inherent limitation to the miniaturization process - cells can only get so small and still be a complete functioning entity with all metabolic systems intact (Raven 1987). The fact that minimum picoeukaryote cell size was reached at the $1 \mathrm{nM}$ DFB addition, and that they did not become smaller with an increase of DFB to $5 \mathrm{nM}$, suggests they may have reached their minimum size rather quickly. While we cannot rule out that a separate species of smaller picoeukaryotes bloomed in our + DFB treatments, the absence of a detectable seed population at the beginning of the experiment for this small size group (data not shown) strongly supports miniaturization.

\section{Implications of shifts in phytoplankton community structure}

Previous studies have suggested that Fe fertilization resulted in a shift in species from smaller picoplankton to larger eukaryotic phytoplankton. In those studies, a direct correlation between an alleviation of Fe-limitation and production by larger diatoms could be attributed to the relationship between cell size and nutrient acquisition (Hutchins et al. 1998).

In the HNLC waters of this region, Hutchins et al. (2002) demonstrated that small diatoms, coccolithophorids and Phaeocystis spp. proliferated in the Feaddition regimes. At Stns Bio-5 and Bio-6, changes in the Si:N drawdown were small but significant $(\mathrm{p}<$ 0.05 ) between $5 \mathrm{nM}$ Fe-enriched (Bio-5 Si:N = $0.248 \pm$ 0.010 ; Bio-6 Si:N = 0.288 \pm 0.019$), 5$ nM DFB added (Bio-5 Si:N = 0.332 \pm 0.035 ; Bio-6 Si: $N=0.117 \pm 0.075$ ) and controls (Bio-5 $=0.266 \pm 0.033$; Bio- $6 \mathrm{Si}: \mathrm{N}=0.238 \pm$ 0.093), resulting in opposing trends: decreasing Si:N with increasing $\mathrm{Fe}$ at Stn Bio-5 and increasing Si:N 
with increasing Fe at Stn Bio-6. Our data from Bio-7 suggest that no differences in silicic acid utilization occurred between treatments. The Bio- 6 results concur with the $\mathrm{Si}: \mathrm{N}$ drawdown ratios observed for $\mathrm{Fe}$ enriched communities at 2 other locations in this region (Hutchins et al. 2002); we hypothesize the differences at Stn Bio-5 are most likely due to differences in initial (and thus final) populations. At Stn Bio-7, combined-N drawdown increased $\sim 177 \%$ with the shift in Fe availabilities, with the results of independent bottles being significantly different from the control at $\mathrm{p}<0.10$ (3 nM DFB, $\mathrm{p}=0.09 ; 5 \mathrm{nM}$ DFB, $\mathrm{p}=0.06$; $10 \mathrm{nM} D F B, p=0.08)$. Interestingly enough, no significant differences $(p<0.10)$ were seen between the controls and any treatments with regard to Si concentrations. While part of this result is probably a manifestation of the observed species shift in the system, it may also be a result of alterations in cellular nitrate scavenging abilities within populations as limitation of nitrate reductase activity (due to enzymatic Felimitation; Raven 1988, Price et al. 1991, 1994) was alleviated. Regardless of the factors causing this shift, the results call into question the universal applicability of $\mathrm{Si}: \mathrm{N}$ drawdown ratios as indicators of community $\mathrm{Fe}$ stress; while there is an effect at each station, the degree of that response appears, in this case, to be somewhat community dependent.

\section{CONCLUSIONS}

Our results here confirm Fe-limitation in upwelling regimes, and demonstrate that the degree of Fe-limitation is not only spatial in nature, but can be group related within a given phytoplankton community. These results further demonstrate that cellular miniaturization is a response used by members of the phytoplankton community (in this case picoeukaryotic algae) to compensate for growth-limiting levels of Fe. Our experiments also confirm that DFB can be used to effectively limit Fe availability to these marine plankton communities. The application of the titration approaches described in this paper to other HNLC regions should provide insight into the group-specific requirements for $\mathrm{Fe}$ in other HNLC environments, ultimately permitting for a quantifiable approach to resolving the degree of Fe-limitation of phytoplankton in HNLC marine systems.

Ecosystem-scale Fe-fertilization proposals cite the potential for Fe fertilization to enhance the export of carbon from the atmosphere to the deep ocean via a combined increase in photosynthesis and enhanced export of biomass (in terms of sinking phytoplankton) from surface waters to the deep ocean. The alterations in the phytoplankton community that would allow for this are critical, as small picoplankton (e.g. Synechococcus and Prochlorococcus spp.) do not play a significant role in export production in marine systems (Boyd \& Newton 1999). This is in part due to their small size and higher buoyancy, but may in part also be due to their enhanced susceptibility to mortality mechanisms (e.g. viral lysis) that can cause increased turnover of carbon as DOC (Suttle \& Chan 1994, Wilhelm \& Suttle 1999). Estimates of $\mathrm{CO}_{2}$ sequestration are generally based on a Redfield drawdown of $\mathrm{NO}_{3}$ by the plankton community relative to the Fe added during the fertilization process (Martin 1990). It appears from our data that models of the effects of $\mathrm{Fe}$ fertilization will also need to consider changes in species composition, cell size and N-utilization, thus emphasizing the need for realistic, experimentally derived, taxon-specific assays in the future.

Acknowledgements. We thank Jenn Conn, Jennifer Maucher, Johanna Rinta-Kanto, Geoff Smith, Richard Weaver and the captain and crew of RV 'Melville' for assistance in collection of samples, and 3 anonymous reviewers for their comments. This work was supported by grants from the National Science Foundation to S.W.W. (OCE-9977040 and OCE-0002968), D.A.H. (OCE-9811062), G.R.D. (OCE-9907931), K.W.B. (OCE-9811114), a University of Tennessee SARIF award to S.W.W., and funds from the Natural Sciences and Engineering Research Council of Canada, and The Center for Environmental BioInorganic Chemistry (CEBIC, Princeton) to C.G.T.

\section{LITERATURE CITED}

Barbeau K, Rue EL, Trick CG, Bruland KW, Butler A (2003) Photochemical reactivity of siderophores produced by marine heterotrophic bacteria and cyanobacteria based on characteristic (Fe III) binding groups. Limnol Oceanogr 48: 1069-1078

Behrenfeld MJ, Bale AJ, Kolber ZS, Aiken J, Falkowski PG (1996) Confirmation in iron limitation of phytoplankton photosynthesis in the equatorial Pacific Ocean. Nature 383:508-511

Boyd PW, Newton PP (1999) Does planktonic community structure determine downward particulate organic carbon flux in different oceanic provinces? Deep-Sea Res Part I 46:63-91

Boyd PW, Watson A, Law CS, Abraham E and 31 others (2000) A mesoscale phytoplankton bloom in the polar Southern Ocean stimulated by iron fertilization. Nature 407: 695-702

Brand L (1991) Minimum iron requirements of marine-phytoplankton and the implications for the biogeochemical control of new production. Limnol Oceanogr 36:1756-1771

Bruland KW, Rue EL, Smith GJ (2001) Iron and macronutrients in coastal upwelling regimes off central California: Implications for extensive blooms of large diatoms. Limnol Oceanogr 46:1661-1674

Chavez FP (1995) A comparison of ship and satellite chlorophyll from California and Peru. J Geo Res Oceans 100: $24855-24862$

Chavez FP, Toggweiler JR (1995) Physical estimates of global new production: the upwelling contribution. In: Summerhayes $\mathrm{CP}$, et al. (eds), Upwelling in the Ocean: Modern 
Processes and Ancient Records, 313-320. John Wiley, New York

Chavez FP, Buck KR, Caole KH, Martin JH, DiTullio GR, Welschmeyer NA, Jacobson AC, Barber RT (1991) Growth rates, grazing, sinking and iron limitation of equatorial Pacific phytoplankton. Limnol Oceanogr 36:1816-1833

Chisholm SW (1992) Phytoplankton size. In: Falkowski PG, Woodhead AD (eds) Primary productivity and biogeochemical cycles in the sea. Plenum, New York, p 213-238

Coale KH, Johnson KS, Fitzwater SE, Gordon RM and 15 others (1996) A massive bloom induced by an ecosystemscale iron fertilization experiment in the equatorial Pacific Ocean. Nature 383:495-500

Daneri G, Dellarossa V, Quinones R, Jacob B, Montero P, Ulloa O (2000) Primary production and community respiration in the Humboldt Current off Chile and associated areas. Mar Ecol Prog Ser 197:41-49

de Baar HJW, Boyd PM (2000) The role of iron in plankton ecology and carbon dioxide transfer of the global oceans. In: Hanson RB, Ducklow HW, Field JG (eds) The dynamic ocean carbon cycle: a midterm synthesis of the joint global ocean flux study. International Geosphere Biosphere Programme Book Series, Vol 5. Cambridge University Press, Cambridge, p 61-140

Firme GF, Rue EL, Weeks DA, Bruland KW and Hutchins DA (2003) Spatial and temporal variability in phytoplankton iron limitation along the California coast and consequences for $\mathrm{Si}, \mathrm{N}$ and $\mathrm{C}$ biogeochemistry. Global Biogeochem Cycles 17:10.1029/2001GB001824

Fogg GE (1995) Some comments on picoplankton and its importance in the pelagic ecosystem. Aquat Microb Ecol 9:33-39

Frankel SL, Binder BJ, Chisholm SW, Shapiro HM (1990). A high-sensitivity flow cytometer for studying picoplankton. Limnol Oceanogr 35:1164-1169

Geider RJ, LaRoche J (1994) The role of iron in phytoplankton photosynthesis, and the potential for iron-limitation of primary productivity in the sea. Photosynth Res 39:275-301

Gorham P, McLachlan JL, Hammet UT, Kim UK (1964) Isolation and culture of toxic strains of Anabaena flos-aquae (Lyngb.). Verh Int Verein Theor Angew Limnol 15: 796-804

Hudson RJM, Morel FMM (1989) Distinguishing between extracellular and intracellular iron in marine phytoplankton. Limnol Oceanogr 34:1113-1120

Hutchins DA, Bruland KW (1998) Iron-limited diatom growth and Si:N uptake ratios in a coastal upwelling regime. Nature 393:561-564

Hutchins DA, DiTullio GR, Zhang Y, Bruland KW (1998) An iron limitation mosaic in the California upwelling regime. Limnol Oceanogr 43:1037-1054

Hutchins DA, Franck V, Brzezinski MA, Bruland KW (1999a) Inducing phytoplankton iron limitation in iron-replete coastal waters with a strong chelating agent. Limnol Oceanogr 44:1009-1018

Hutchins DA, Witter AE, Butler AE, Luther GW III (1999b) Competition among marine phytoplankton for different chelated iron species. Nature 400:858-861

Hutchins DA, Hare CE, Weaver RS, Zhang Y and 11 others (2002) Phytoplankton Fe limitation in the Humboldt Current and Peru Upwelling. Limnol Oceanogr 47:997-1011

Kudo I, Miyamoto M, Noiri Y, Maita Y (2000) Combined effects of temperature and iron on the growth and physiology of the marine diatom Phaeodactylum tricornutum (Bacillariophyceae). J Phycol 36:1096-1102

Laws EA, DiTullio GR, Carder KL, Betzer PR, Hawes S (1990) Primary production in the deep blue sea. Deep-Sea Res
37:715-730

Lluch-Cota SE (2000) Coastal upwelling in the eastern Gulf of California. Oceanol Acta 23:731-740

Madigan MT, Martinko JM, Parker J (2000) Brock biology of microorganisms. Prentice-Hall, Upper Saddle River, NJ

Maldonado MT, Price NM (1999) Utilization of iron bound to strong organic ligands by plankton in the subarctic Pacific Ocean. Deep-Sea Res 46:2447-2473

Maldonado MT, Price NM (2001) Reduction and transport of organically bound iron by Thalassiosira oceanica (Baccillariophyceae). J Phycol 37:298-309.

Martin JH (1990) A new iron age, or a ferric fantasy. US JGOFS Newsl 1:5-11

Martin JH, Gordon RM (1988) Northeast Pacific iron distributions in relation to phytoplankton productivity. Deep-Sea Res 35:177-196

Martin JH, Coale KH, Johnson KS, Fitzwater SE and 40 others (1994) Testing the iron hypothesis in ecosystems of the equatorial Pacific Ocean. Nature 371:123-129

Martinez JS, Haygood MG, Butler A (2001) Identification of a natural desferrioxamine siderophore produced by a marine bacterium. Limnol Oceanogr 46:420-424

Morita RY (1975) Psychrophilic bacteria. Bacteriol Rev 39: 144-167

Muggli DL, Lecourt M, Harrison PJ (1996) Effects of iron and nitrogen source on the sinking rate, physiology and metal composition of an oceanic diatom from the subarctic Pacific. Mar Ecol Prog Ser 132:215-227

Parsons TR, Maita Y, Lalli CM (1984) A manual of chemical and biological methods for seawater analysis. Pergamon Press, New York

Price NM, Harrison GI, Hering JG, Hudson RJM, Nirel PMV, Palenik B, Morel FMM (1989) Preparation and chemistry of the artificial algal culture medium Aquil. Biol Oceanogr 6:443-461

Price NM, Andersen LF, FMM Morel (1991) Iron and nitrogen nutrition of the equatorial Pacific plankton. Deep-Sea Res 38:1361-1378

Price NM, Ahner BA, Morel FMM (1994) The equatorial Pacific Ocean: grazer-controlled phytoplankton populations in an iron-limited ecosystem. Limnol Oceanogr 39: $520-534$

Raven JA (1987) Physiological consequences of extremely small size for autotrophic organisms in the sea. Can Bull Fish Aquat Sci 214:1-70

Raven JA (1988) The iron and molybdenum use efficiencies of plant growth with different energy, carbon and nitrogen sources. New Phytol 109:279-287

Rue EL, Bruland KW (1995) Complexation of iron(III) by natural organic ligands in the Central North Pacific as determined by a new competitive ligand equilibration/adsorptive cathodic stripping voltammetric method. Mar Chem 50:117-138

Rue EL, Bruland KW (1997) The role of organic complexation on ambient iron chemistry in the Equatorial Pacific Ocean and the response of a mesoscale iron addition experiment. Limnol Oceanogr 42:901-910

Sherman DM, Sherman LA (1983) Effect of iron deficiency and iron restoration on ultrastructure of Anacystis nidulans. J Bacteriol 156:393-401

Soria-Dengg S, Horstmann U (1995) Ferrioxamines B and E as iron sources for the marine diatom Phaeodactylum tricornutum. Mar Ecol Prog Ser 127:269-277

Sunda WG, Swift DG, Huntsman SA (1991) Low iron requirement for growth in oceanic phytoplankton. Nature 351: $55-57$

Suttle CA, Chan AM (1994) Dynamics and distribution of 
cyanophages and their effect on marine Synechococcus spp. Appl Environ Microbiol 60:3167-3174

Timmermans KR, Gerringa LJA, de Baar HJW, Van Der Wagt B, Veldhuis MJW, De Jong JTM, Croot PL (2001) Growth rates of large and small Southern Ocean diatoms in relation to availability of iron in natural seawater. Limnol Oceanogr 46:260-266

Trick CG, Wilhelm SW (1995) Physiological changes in the coastal marine cyanobacterium Synechococcus sp. PCC 7002 exposed to low ferric ion levels. Mar Chem 50:207-217

Wells M (1999) Manipulating iron availability in nearshore waters. Limnol Oceanogr 44:1002-1008

Wells M, Price NM, Bruland KW (1994) Iron limitation and the cyanobacterium Synechococcus in equatorial Pacific waters. Limnol Oceanogr 39:1481-1486

Welschmeyer NA (1994) Fluorometric analysis of chlorophyll $\mathrm{a}$ in the presence of chlorophyll $\mathrm{b}$ and pheopigments. Limnol Oceanogr 39:1985-1992

Wilhelm SW (1995) The ecology of iron-limited cyanobacte-

Editorial responsibility: Paul Harrison,

Kowloon, Hong Kong ria: a review of physiological responses and implications for aquatic systems. Aquat Microb Ecol 9:295-303

Wilhelm SW, Suttle CA (1999) Viruses and nutrient cycles in the sea. Bioscience 49:781-788

Wilhelm SW, Trick CG (1994) Iron-limited growth of cyanobacteria: multiple siderophore production is a common response. Limnol Oceanogr 39:1979-1984

Wilhelm SW, Trick CG (1995) Physiological profiles of Synechococcus (Cyanophyceae) in iron-limiting continuous cultures. J Phycol 31:79-85

Wilhelm SW, Maxwell DP, Trick CG (1996) Growth, iron requirements, and siderophore production in iron-limited Synechococcus PCC 7002. Limnol Oceanogr 41:89-97

Wilhelm SW, Macauley K, Trick CG (1998) Evidence for the importance of catechol-type siderophores in the iron-limited growth of a cyanobacterium. Limnol Oceanogr 43:992-997

Winkelmann G (1991) Specificity of iron transport in bacteria and fungi. In: Handbook of microbial iron chelates. CRC Press, Boca Raton, FL, p 65-106

Submitted: May 26, 2003; Accepted: November 23, 2003

Proofs received from author(s): March 3, 2004 